\section{MAGNETIC VARIATIONS. ${ }^{1}$}

$\mathrm{I}$ this paper the author refers to the ordinary variations of the magnetic elements as observed at Greenwich; the annual progressive change; the diurnal variation-large in summer, small in winter, and also larger when sun-spots are numerous and smaller when sun-spots are few ; the irregular magnetic disturbances and magnetic storms, and the accompanying earth currents ; phenomena which are generally similar at other places.

$\mathrm{He}$ then invites attention more particularly to magnetic disturbances. Those at Greenwich may, after a calm period, arise gradually or commence with great suddenness. When sudden, the movement is simultaneous in all elements. The first indication may he a sharp, premonitory, simultaneous movement, followed after a time by general disturbance, or the movement may at once usher in the disturbance. These initial movements are not always great in magnitude, sometimes, indeed, small, but they have a very definite character, and frequently occur nearly instantaneously, as is shown in the character of the photographic traces.

It has been long known that magnetic disturbances occur at the same time over wide areas of the earth's surface, but the accidental comparison in past years of the times of commencement of one or two disturbances at Greenwich with the times at other places has led the author to suppose that the coincidence in time is much closer than had been before supposed, and the definite, and on occasions isolated, character of the initial movement induced him to undertake the collection and comparison of the times of such movements for a number of days at observatories geographically widely separated.

The times of such movements cannot be caught by eye observation without continuous watching of the magnets, so that the photographic registers have to be relied upon, which is better, excepting that the scale of time is necessarily contracted; but, though in individual measures there might be variations, it was conceived that (supposing no systematic error to exist) the mean of a number of comparisons should give a good result. Seventeen days, occurring in the years 1882 to 1889 , were selected for comparison, the observatories being those of Toronto, Greenwich, Pawlowsk, Mauritius, Bombay, Batavia, Zi-ka-wei, and Melbourne, and, for a less number of days, Cape Horn (as obtained from the Mission Scientifique du Cap Horn, 1882-83). It was desired to have times for Pola, bu: it was found that photographic registers during great part of the period did not exist. The variation in time at each place from the mean of times for all places is given for each day. The mean deviation at the different places varies from +2.4 minutes to -2.9 minutes, the agreement between four of the placesGreenwich, Pawlowsk, Mauritius, and Bombay-being very much closer, the mean values of deviation for Greenwich, Pawlowsk, and Bombay differing, indeed, by only O.I minute, equivalent to 6 seconds.

The question arises, Are the differences real, or due (considering the contracted time scale) to accidental error? If the magnetic impulse is really simultaneous over the whole earth, it is a striking physical fact, and if not entirely so, the circumstance is no less interesting; but greater attention to accuracy of time scale, or a more extended scale, may be necessary before the point in question can be definitely settled.

A table is added, showing the character of the magnetic movement at the several observatories, from which it appears that at any one place the movements on different days were in most cases similar, though different at different places, indicating on these occasions the occurrence usually of one general type of disturbance.

Reference is made to the question of earth currents. A comparison for thirty-one days, between 1880 and I891, of cases of sudden magnetic movement and earth current at Greenwich, shows the earth current to precede the magnetic movement by 0.14 minute, equivalent to 8 seconds. The question of the relation between magnetic movements and earth currents is discussed.

The desirability of being able temporarily to obtain, when occasion requires, a more extended time scale for all magnetical and meteorological phenomena is pointed out.

The general result is that in the definite magnetic movements

"Abstract of paper " On the Simultaneity of Magnetic Variations at different places on occasions of Magnetic Disturbance, and on the relation between Magnetic and Earth Current Phenomena,"' by William Ellis, F.R.A.S., Superintendent of the Magnetical and Meteorological Department, Royal Observatory, Greenwich. Communicated to the Royal Society, on May 5, 1892, by W.H. M. Christie, F.R.S., Astronomer-Royal.

No. II 77 , VOL. 46] preceding disturbance the magnets at any one place are simultaneously affected; also that in places widely different in geographical position the times are simultaneous, or nearly so, a small constant difference existing at some places which may be real or may be accidental, but the character of which it seems desirable to determine. It is shown also that atGreenwich definite magnetic movements are accompanied by earth current movements which are simultaneous, but that neither magnetic irregularities nor ordinary magnetic variations seem to admit of explanation on the supposition of being produced by the direct action of earth currents.

\section{SCIENTIFIC SERIAIS.}

American Fournal of Science, May.-Radiation of atmospheric air, by C. C. Hutchins. A stream of hot air was arranged so that it could be made to pass in front of one of the faces of a thermopile at a distance of $3 \mathrm{~cm}$., and cause a deflection of a galvanometer needle, or the air could be discharged high above the thermopile, leaving it unaffected except by radiation from a large Leslie cube containing water at the temperature of the laboratory. There was no sort of agreement between measures made on eight different days to determine the absolute radiating power of a column of air 1 centimetre thick at a temperature near $100^{\circ} \mathrm{C}$.; but in an ordinary room and under average conditions the value came out $=0.00000$ I $133+$ 0.030000007 I I $\left(t-t^{\prime}\right)$, where $t-t^{\prime}$ is the difference in temperature between the air and the cube. Tyndall's result, that the radiation increases with the amount of moisture in the air, was confirmed, but no exact law of connection between the two was found. This is probably due to the presence of accidental impurities in the air employed. The increase of radiation proves to be proportional to the increase of temperature. There was a small increase of radiating power when sheets of air more than I centimetre thick were used; with sheets less than this thickness, no difference of radiation could be detected.-Atmospheric radiation of heat and its importance in meteorology, by Cleveland Abbe. In this interesting and exhaustive paper Prof. Abbe brings together practically all the conclusions that have been arrived at on atmospheric movements and their relation to radiation from the air. In his words, "A comprehensive study of fluid motions shows that air and water alike may be forced to ascend without being warmer and lighter, or to descend without being colder and denser, than the surrounding fluid. The currents and whirls behind any obstacle in streams of air or water are almost wholly independent of differences of density, and are caused by differences of pressure as modified by simple kinetic laws." These motions, which the air is furced to take for purely kinetic reasons, are specially discussed in detail, but it is impossible to enumerate, in an abstract, the many cases considered.-Experiments upon the constitution of certain micas and chlorites, by F. W. Clarke and E. A. Schneider. The minerals analyzed are waluewite, v. of xanthophyllite, clinochlore, leuchtenbergite, diallage, serpentine, and mica from Miask, Ural.-On the qualitative separation and detection of strontium and calcium by the action of amyl alcohol on the nitrates, by P. E. Browning.--The age and origin of the Lafayette formation, by Eugene W. Hilgard. -On the influence of swamp waters in the formation of the phosphate nodules of South Carolina, by Dr. Charles L. Reese. From the experiments it appears probable that both carbonic acid and the humus substances in fresh-water swamps play an important part both in the accumulation and the concentration of calcium phosphate, and thus in the formation of phosphate nodules, these being considered to be phosphatised marls. Plattnerite, and its occurrence near Mullars, Idaho, by William S. Yeates ; with crystallographic notes by Edward F. Ayres. On the occurrence of Upper Silurian strata near Penobscot Bay, Maine, by William W. Dodge and Charles E. Beecher.-Zincbearing spring waters from Missouri, by W. F. Hillerbrand. The chief constituent salt in the spring in question is zinc sulphate. It forms about 56 per cent. of the total dissolved solids. -A meteorite from Central Pennsylvania, by Prof. W. G. Owens. A chemical analysis of the meteorite gave $\mathrm{Fe} 91 \cdot 36$, $\mathrm{Ni} 7 \cdot 56$, Co $0^{\prime} 70, \mathrm{P} 0.09, \mathrm{~S} 0^{\circ} 06, \mathrm{Si}$ trace $=99^{\circ} 77$. - On two meteoric irons, by G. F. Kunz and E. Weinschenk. One of the masses examined came from Indian Valley Township, Floyd County, Virginia ; the other from Sierra de la Ternera, Province of Atacama, Chili.-The molecular masses of dextrine and gum 
arabic as determined by their osmotic pressures, by C. E. Linebarger. The molecular mass of gum arabic is found to be about 2500 , of dextrine 1134, and of colloid tungstic acid 1750. In each of these three cases the colloid molecule is seven times the simple molecule.

American Fournal of Mathematics, vol. xiv., No. 2. (Baltimore, Johns Hopkins Press, April r892.) - The number before us opens with a paper entitled "Some Theorems relating to Groups of Circles and Spheres," by Prof. W. Woolsey Johnson (pp. 97-II4). The title at once calls to mind Mr. Lachlan's memoir "On Systems of Circles and Spheres" (Phil. Trans., vol. 177). The author thus puts the connection between the papers: "(I) If there be 5 circles or 6 spheres in each group, the product or determinant of powers is equal to zero ; and (2) if there be 4 circles or spheres in each group, the power determinant is the product of two determinants each of which depends upon one of the groups." Mr. Lachlan's results are derived principally from the first of the above theorems, whereas it is Prof. Johnson's object "to point out some other results derivable from the second theorem, and particularly to evaluate the power determinants for groups of smaller numbers of circles and spheres." The two memoirs are an interesting application of a "Theorem in the Geometry of Position" (the multiplication of two determinants) due to Cayley (Castb. Math. Fourn., vol. ii, 1841 ). - The next paper, by C. H. Chapman, is an "A pplication of Quaternions to Projective Geometry" (pp. II 5 40). - Then follows an adaptation of G. W. Hill's method (American Fournal of Mathematics, vol. i.) "so as to include that class of inequalities which depends also on the ratio of the solar and lunar distances, and, in particular, the principal part of the parallactic inequality," by E. W. Brown. The title of the paper is "On the part of the Parallactic Inequalities in the Moon's Motion, which is a Function of the Mean Motions of the Sun and Moon" (pp. 14i-60).-The two remaining papers were read before the New York Mathematical Society, viz. "On the Curves which are self-reciprocal in a Linear Nulsystem, and their Configurations in Space," by C. P. Steinmetz ( $\mu$ p. I6I-86); and "A Classification of Logarithmic Systems," by Irvirig Stringham (pp. 187-94). - This last is an attempt to use the logarithmic spiral, defined as a geometrical locus, as the means for defining the logarithm and demonstrating its properties.

Bulletin of the New York Mathematical Society, vol. i. Nos. 6, 7 (New York: March, April, 1892). - The first of these numbers opens with a discussion of the mechanical axioms, or laws of motion, as presented by Newton. The author, Prof. W. Woolsey Johnson, examines at some length (pp. 129-39) the views put forward in Thomson and Tait, "Natural Philosophy"; Tait, "Mechanics" " Encyc. Brit."); and Williamson and Tarleton, "Dynamics." The article is a careful piece of reasoning, founded upon the principle that " it is desirable to include among the axioms of mechanics the smallest basis of postulated principles upon which it is possible to construct the science by rigid mathematical reasoning." Then follow short notices of an 8-figure logarithm table, published "par ordre du Ministre de la Guerre, Paris, 189r," and of "An Introduction to Spherical and Practical Astronomy, by Dascom Greene (Boston, 1891)." The usual "Notes" and list of new publications close this number and also No. 7. This last-named number opens with a review of "The Laws of Motion, an Elementary Treatise on Dynamics, by W. H. Laverty." The writer's object in this, and similar articles that are to follow, is " by reviewing somewhat at length a few of the better recent works on elementary mechanics to 'fix the ideas' and arrive at some conclusions, at least, as to what is the best modern usage in treating the subject" (pp. 145-50). The next contribution, by Dr. C. H. Chapman, entitled "Weierstrass and Dedekind on General Complex Numbers" (pp. 150-56), is one of those that makes this Builetin so interesting and valuable to the student. The last article is a translation (pp. $156-68$ ) by Prof. Ziwet of an éloge by M. Duhem on "Emile Mathieu : His Life and Works."

Memoirs of the St. Petersburg Society of Naturalists, vol. $\mathrm{xxi}$. (Section of Botany). - Besides the proceedings, the volume contains the first part of an excellent monograph, by $M$. Aggéenko, on the flora of Crimea, being a description of the botanical geography of the peninsula. The orography and hydrography of Crimea, and its various soils, are shortly described, as also its climate. The periodical phenomena of blooming and fruit-bearing are next dealt with. The follow-

NO. I I 77 . VOL. 467 ing chapter is devoted to the analysis of previous exploration, and the remainder of the work is given to the description of the character of vegetation in the Steppes of Crimea, on the northern slope of the highlands, the flat summits of the Yaila highlands, and especially the southern slope. The influence of man and of the fauna on vegetation is briefly treated, and a new species, Alyssum rotundatum, as well as a new variety of Orchids (Ophrys aranifera, Hudson, var. taurica) are described and figured on plates. A very interesting geo-botanical map of Crimea is given.-A paper on the pigments of Fungi, by A. Nadson, must be rather considered as a preliminary communication, containing many valuable data on the pink, yellow, red, and orange pigments of some fifteen species. - On the crystals in the leaves of the Anonacee and:Violariece, by Prof. Borodin.

Vol. xxii. (Section of Zoology and Physiology).-Ornithological observations in the middle course of the Amu-daria in the Tcharjui-kelif region, by A. Yaschenko. A list of $16 \pi$ species of birds and their distribution in various regions (cultivated, mixed, deserts, and mountains) is given, each of the regions being described separately as to its most characteristic birds. On the hybrids between Butydes flava and Butydes campestris, by N. Zaroudnoi. - On the embryonal development of Phyllodromia (Blatla) Germanica, by N. Kholodkovsky, being a very elaborate and valuable contribution to comparative embryology. It is the fruit of a four years' laborious research, and is accompanied by five large well-drawn plates.

Bulletin de l'Académie des Sciences de St. Pétersbourg, Nouvelle Série, t. ii., No. 3. - The ephemeris and the approximate elements of the comet of Encke for the year 189I, by O. Backlund (in German). The ephemeris is calculated from July 2 to November I, I89I, after having taken into account the perturbing influences of Venus, the Earth, Mars, and Jupiter in 1884-88, and Jupiter alone from March 7 , I 888 , to May 31, 1891.-Additions to the Flora of the Caucasus: i. Two new varieties of Rhamnus, by N. Kuznetsoff (in German, with two plates). - On the radiants of the Andromedides, by Th. Bredikhine (in French), with a plate. The meteoric current of November 27,1872 , and 1885 is studied, the former on the ground of the observations of the Brera Observatory at Milan. The positions of the radiants are given on a map, upon which the orbit of the comet of Biela (for 1859) is also traced. The positions of the radiants being taken into account, the author compares the probable elements of the meteoric current with the orbit of the Biela comet. Taking further into account the meteoric currents observed on December 7 and 8 in $1798,1830,1838$, and 1848 , the author concludes that those currents must have belonged to the orbit of the same comet before the severe perturbations it suffered through the influence of Jupiter in 1794.--Observations of $5 \mathbf{1}$ double stars, followed by a research into systematic errors, by F. Renz, of Pulkova (in German). The observations and the catalogue based upon them are given.On some old and new catalogues of stars, by J. Seyboth (in German). Before the printing of Romberg's catalogue a comparison of its data with those of previous catalogues was felt to be necessary. A series of comparative measurements has been undertaken for that purpose, and their results are given in the introduction to Romberg's catalogue. Further comparison is now made with the catalogues of Struve, Argelander, Pulkova (3542 stars), Becker, and Gould, and reduction tables are given.-A new Bacterium, Nevskia ramosa, by A. Famintzin (in German), with a plate. This strange organism, so widely different from all known Bacteria, but not unlike to Metchnikoff's Pasteuria ramosa, consists of a jelly-like ramified growth, the Bacteria cells appearing upon the ends of the branches. It forms colonies similar to those formed by some Algæe and Infusoria (Urococcus, Gomphonema, Epistylis). - On the libration of Hyperion, by H. Struve (in French). The last years' observations of this satellite of Saturn, which have been made with the aid of the great Pulkova refractor, having disclosed considerable discrepancies from the ephemerides calculated by Mr. Marth, the Pulkova astronomer tried to explain them-and succeeded to a great extent-by a libration which has a short period of 641 days, and an amplitude of $9^{\circ}$ in the average longitude. - Revision of the Hymenopteres of the Zoological Museum of the Academy, by A. Semenoff: i. Genus Cleptes (in Latin). The following new species are described: Cleptes flammifer, obsoletus, Buyssonis, and Mocsarii; ii. Genus Abia (new species): A. symballophthalma.-New Gentianæ from Asia, by N. Kuznetsoff. The following new species, some of which had already been recog 
nized as new by Maximowicz, are described: Gentiana Maximowiczi, leucomelana, purpurata, siphonantha, Regeli, glomerata, and G. Kuroo, var. brevidens. They are from Central Asia, North China, and Mongolia.-Report of the International Meteorological and Polar Conferences, and the International Committee of Weights and Measures, by $\mathrm{H}$. Wild. No. 4: Remarks on Mr. Kock's work, "Comicorum Atticorum fragmenta" (in German).

\section{SOCIETIES AND ACADEMIES.}

\section{LONDON.}

Royal Society, May 5--"Transmission of Sunlight through the Earth's Atmosphere. Part II. Scattering at Different Altitudes." By Captain W. de W. Abney, C.B. D.C.L., F.R.S.

In this paper the results of observations made by exposing platinotype paper are recorded, and it is shown that the tota intensity of light as thus registered is the same as if observations had been made on a ray of $\lambda 4240$ alone. The observations were made at altitudes varying from sea-level to 12,000 feet in different countries, at different times of the year, and during four to five years. The instrument in which the ex posures were made is described, as also the method of deriving the intensity of light from the developed prints. The results of these observations agree closely with those obtained by the measures of the spectrum which was described in Part I. of this subject. The value of $k$ in the formula (I) $\mathrm{I}^{\prime}=\epsilon^{-k \lambda^{-4} x}$ (from which can be calculated the loss of intensity of a ray of any particular wave-length) was found to be 0.00146 at sealevel. It was also found that $k$ apparently varied as $h^{2}, h$ being the barometric pressure. A table is attached, showing the value of the transmitted light in the formula (2) $\mathrm{I}^{\prime}=\mathrm{I} \alpha_{x}$, where $a$ is a constant and $x$ the air thickness in terms of the vertical thickness, $\mu$ being the formula $\mathrm{I}^{\prime}=\mathrm{I} \epsilon^{-\mu . x}$, from which (I) and (2) are both shown to be derived.

\begin{tabular}{c|c|c||c|c|c}
\hline $\begin{array}{c}\text { Bar } \\
\text { in inches. }\end{array}$ & $\mu$. & $a$. & $\begin{array}{c}\text { Bar } \\
\text { in inches. }\end{array}$ & $\mu$. & $a$. \\
\hline & & & & & \\
30 & 0.154 & 0.856 & 24 & 0.098 & 0.908 \\
29 & 0.144 & 0.866 & 23 & 0.090 & 0.915 \\
28 & 0.134 & 0.875 & 22 & 0.083 & 0.922 \\
27 & 0.124 & 0.884 & 21 & 0.075 & 0.928 \\
26 & 0.115 & 0.891 & 20 & 0.068 & 0.934 \\
25 & 0.107 & 0.899 & 19 & 0.062 & 0.940 \\
\hline
\end{tabular}

Linnean Society, April 21.-Prof. Stewart, President, in the chair.-An example of an Australian bird (Gymnorhina), which had lately been shot near Tor Abbey, Devonshire, after being observed all the winter, and which had doubtless escaped from confinement, was exhibited on behalf of Mr. W. Else, Curator of the Torquay Museum.-On behalf of Mr. Charles Head, of Scarborough, two specimens of the Whiskered Bat (Vespertilio mustacinus) taken in that neighbourhood were exhibited.-Mr. W. B. Hemsley, F.R.S., read a paper entitled "Observations on a Botanical Collection made by Mr. A. E. Pratt in Western China, with descriptions of some new Chinese plants from various collections." Mr. Pratt travelled in 1889-90 in Western China, close on the borders of Eastern Tibet, and though chiefly in search of zoological specimens, he fortunately secured the services of a native who had been trained to dry plants by Dr. Henry, the result being that he was enabled to bring home a very interesting botanical collection. The plants were obtained chiefly at elevations of 9000 to 13,500 feet, in the neighbourhood of Tat-sien-lu, a frontier town situated in about $30^{\circ} \mathrm{N}$. lat. and $102^{\circ} 15^{\prime} \mathrm{E}$. long. ; and although Mr. Hemsley reported that he had not finished working out the collection, he estimated that it contained about 500 species, of which perhaps I 50 species were new to science. The paper was criticized by Mr. C. B. Clarke, who remarked that the mountain ranges of Western China seemed to abound in showy herbaceous plants, rivalling in this respect the richest districts of the Himalayan region, of which, in fact, it is a continuation.-Mr. H. M. Bernard then gave an NO. I I 77, VOL: 46] abstract of a paper on the relation of the Acaridæ to the Arachnida, in which he argued that the former were fixed larval forms of the latter; though he found a difficulty in dealing with the segmentation, this being so profoundly modified and in some cases lost. The paper was criticized by $\mathrm{Mr}$. A. D. Michael, Mr. Breeze, and Prof. G. B. Howes, all of whom, while testifying to the ingenuity of Mr. Bernard's reasoning, considered that there was hardly as yet sufficient evidence to justify the acceptance of his conclusions.

May 5.--Prof. Stewart, President, in the chair.-On behalf of Mr. Holt, Prof. G. B. Howes exhibited and made remarks on a very interesting collection of the metamorphosing larvæ of flat-fish.-Mr. Curtis showed a photograph of sections of the Silver and Douglas firs, illustrating the relative rate of growth in trees of the same age growing in the same soil and under similar conditions in all respects, the diameter of the one (A. Douglasii) being nearly double that of the other. - Mr. George Murray exhibited spirit specimens of Ascothamnion intricatum, an organism described as a siphoneous Alga, but ascertained to be identical with an animal-namely, Zoobotryon pellucidum, Ehrenberg. He also exhibited two specimens of a palm (Thrinax Morrisii, Wright), peculiar to Anguilla in the Leeward Islands, and made some remarks as to the results of the recent cryptogamic collections made by $\mathrm{Mr}$. W. R. Elliott for the West India Committee. - Mr. Holmes exhibited and made some observations on an abnormal development of the calyx in a primrose.-The President exhibited and explained a collection of Lepidoptera containing several examples of mimicry between protected forms. - On behalf of Dr. J. Müller, Mr. Thiselton Dyer communicated a paper entitled "Lichenes Epiphylli Spruceani."-Mr. W. F. Kirby gave an abstract of a paper on the family Saturnide, with descriptions of new species in the British Museum.-In the absence of the author, Mr. W. Percy Sladen read a paper by the Rev. Hilderic Friend, entitled "Observations on British Earthworms."-The President announced that the anniversary meeting of the Society would be held on May 24, at 3 p.m.

Royal Microscopical Society, April 20.-The President, Dr. R. Braithwaite, in the chair.-Mr. A. W. Bennett called attention to some slides received from Prof. D. P. Penhallow, of Montreal, who sent them to illustrate an improved method of labelling. Instead of writing upon the usual paper label, he writes directly upon the glass, and covers the writing afterwards with a thin coating of Canada balsam, which makes it permanent. - Prof. F. Jeffrey Bell said that, the Council having concluded the negotiations with their landlords, the rooms of the Society would now be open for the use of the Fellows every Wednesday evening from 6 to 10 p.m., from November till June. This order would take effect at once.-Mr. F. Chapman's paper onthe Foraminifera of the Gault of Folkestone was read.Surgeon P. W. Bassett-Smith's paper on the deep-sea deposits ot the Eastern Archipelago was read by Prof. Bell. H.M.S. Pen ruin, to which Surgeon Bassett-Smith was attached, made a passage during the latter part of $\mathrm{I} 8 \mathrm{gI}$ from Port Darwin, North-west Australia, through the Arafora, Banda, Celebes, Sulu, and China seas to Hong Kong. A continuous and close line of soundings was taken through the whole passage, the deepest water being 2880 fathoms in the Banda Sea. In almost every instance specimens of the bottom were obtained. They consisted mostly of "green muds," with a few "blue" and "brown muds" in the cireper parts. The definition of "green mud" is a very wide one; broadly it may be divided into that in which calcareous organisms, chiefly Globigerina, predominate, and that in which the tests of Radiolarians have taken their place; this latter condition was almost always present in " brown muds." The inorganic materials were either fine quartz sand in the deeper and more distant positions, or, as the coast was approached, argillaceous matter together with sponge spicules and small shells. In places the material was typically volcanic, as in the upper part of the Banda Sea, among the Moluccas, and on the coast of Luzon. Only two specimens of pure Globigerina ooze were obtained, both being in the Molucca passage, one in 1885 fathoms and the other in 197 fathoms. It would seem that in the deeper parts of the seas the bottoms consist of Radiolarian muds, and the shallower parts of Globigerina muds, the line being roughly drawn at 1500 fathoms. In almost every case over 2000 fathoms the siliceous organisms were undoubtedly most abundant. - A note was read from Dr. E. Giltay on the use of the camera lucida in drawing Bacteria, 